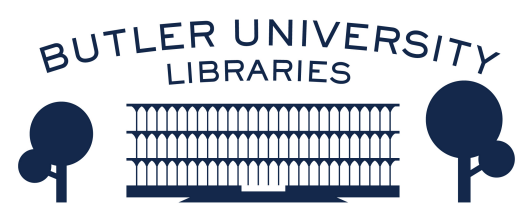

Journal of Hindu-Christian Studies

\title{
Book Review: "Nama Japa: Prayer of the Name in the Hindu and Christian Traditions"
}

C. Murray Rogers

Follow this and additional works at: https://digitalcommons.butler.edu/jhcs

Part of the Religion Commons

\section{Recommended Citation}

Rogers, C. Murray (1997) "Book Review: "Nama Japa: Prayer of the Name in the Hindu and Christian Traditions"," Journal of Hindu-Christian Studies: Vol. 10, Article 26.

Available at: https://doi.org/10.7825/2164-6279.1172

The Journal of Hindu-Christian Studies is a publication of the Society for Hindu-Christian Studies. The digital version is made available by Digital Commons @ Butler University. For questions about the Journal or the Society, please contact cbauman@butler.edu. For more information about Digital Commons @ Butler University, please contact digitalscholarship@butler.edu. 
world of religion and spirituality. This extremely well-documented work has also a good index of concepts and text references as well as an extensive bibliography.

The Hindu concept of cyclic cosmic creations and destructions have been noted frequently by international conferences and studies on time. The first congress of International Society for the Study of Time (1969) had brought the Hindu concepts to the notice of a wider circle of scientific scholarship. The discussion, however, has turned round mostly on cyclic and linear differences in the perception of history. Wessler tries to get out of these stereotypes which he considers not only as questionable but also misleading in the complexity of the Hindu perception of time.

Wessler's analysis brings to light to what extent the Viṣnupurāna gives a marked importance to discussions on time in its soteriology. Its quest for bhakti as the highest means of salvation does not eliminate the element of time. On the contrary, it tries to incorporate it in its theology as the necessary condition for the realization of salvation. The significance of time, however, is not consistent in all the pralaya. Its cyclic notion of it is not exactly what Western thought often makes of the contrast to the linear idea of history. Moreover, the Visnupurāna proposes the cyclic concept only as one among-many other perceptions of time.

Anand Nayak

University of Fribourg

\section{Nama Japa: Prayer of the Name in the Hindu and Christian Traditions. Vandana Mataji. Delhi: Motilal Banarsidass, 1995, 268pp.}

I HAVE HEARD it said that there is no such thing as delay with the Spirit, that everything happens at the right moment. It having taken me quite a time of hard work to let it percolate a little into my mind and heart, I suspect that it is not by chance that this book by Vandana Mataji has arrived at this moment.

One could be forgiven for thinking that it is concerned with one type of prayer, even a restricted method of prayer, but how mistaken one would be! Nothing narrow here for either the Hindu or the Christian, something much more than an idea or theological view and practice to be analysed. Vandana Mataji presents us rather with a way of life, a tool for our human liberation, demanding all we have, nearer to being a fire than a concept.

Nama Japa, the Prayer of the Name in the Hindu and Christian traditions is almost an encyclopedia. Others, better practised in this "way", might find something missing; I have tried, but have failed. This makes it a very substantial book, hard work, and even harder work in the practising. The first 75 pages are the Praxis, the doing/living of the Prayer of the Name. How right it is that Praxis comes first! Abstract knowledge, of which there is much in Part II, Theory, is nothing more than what Zen people would call "third leg of chicken", unreal and useless, unless it flows from direct experience. If we hope for growth and wisdom from this way of nama japa, then we must always stay with the practice.

Nama means "name"; Japa means "repetition" - repetition of a Name of God. The Praxis part then takes one, in some detail, through japa in each one of its manifestations in the woman or man who is on this human/spiritual path, japa, i.e. with mala or rosary, with pen, with music, with rhythm, with breath-awareness, with anusthana and purascarana, with the Word of God, personally and in groups. This spiritual path is certainly a life involvement and we are not allowed for a minute to 
forget it.

If any of us was tempted before reading this book to imagine that our way was the one and only way - whether Hindu or Christian - how greatly the facts of human experience in each religion deny that arrogance and blindness! This is a book that tackles our similarities and our differences very frankly, without for a moment attempting to reduce to a monochrome the extraordinary variety involved in the experience or practitioners.

Part II is concerned, then, with Theory, a detailed and thorough examination of the place and tradition of this prayer of the heart and power of the Name in both Christian and Hindu Scriptures and history. And what a host of material there is, in both! The chapter on "The Name in Christian Scriptures and the Early Church" rightly includes sections on the rabbinical tradition and the Cabalists and one is left in no doubt that the invocation of the Name of God goes back to the very grounds of our Christian way, a living tradition which has been, and too often still is, largely neglected. From there we are immediately plunged into the Name in Hindu Scriptures and Tradition, a fullness of teaching from Hinduism's prehistoric past and the first realization of the pranava mantra $O M$ in Vedic times and the experiencing of God as sound and silence in the Maitri Upanisad and all the way to our modern saints and teachers. From there it is a small step to the consideration of the Power of the Name in both of our living traditions. In both the power belongs to the Eternal and for a human being, in East and West, to fix the Name in the heart is to discover a freedom from fear and from anger/violence, and a freedom for love and service, as much in life as in death. It is not by chance that Gandhiji died with Ram Ram on his lips. As the author says, "There is literally no end to the spheres in which the Name demonstrates its power."

The prayer of the Name in the Eastern Orthodox Church - with its many good echoes in "The Way of the Pilgrim" and the Philokalia - is, especially for a Christian reviewer, a very rich chapter leading into a consideration of the Mantra, that voicing of sacred syllables which lets loose a dynamic power both in the Hindu sadhaka and in the disciple of Christ. Throughout the book it is the deeply respectful attitude of the writer which is as great a gift as the material shared. In a time of fear of relativism and of fundamentalism on all sides such respectful attitudes and practice are of very great importance.

The last section, after Praxis and Theory, is to introduce to readers a great cloud of witnesses, the saints who have loved the Name. Here we find Hindu poetsaints, both ancient and modern, Sikh spiritual masters, Muslim Sufis, Buddhist followers of the Nambutsu tradition, the prophets of Israel, and a host of Christian "singers of the Name". The list is overwhelming!

As Swami Abhishiktanadaji (dom Le Saux), whose presence is almost tangible throughout this book, said so often to us, the prayer of the heart begins and ends with silence, not simply the silence of words, but of a person's whole being. The singers of the Name introduced to us by Vandana Mataji convey the same challenge. In our age of many words and much noise this asks of us a great deal.

A notable book indeed!

C. Murray Rogers 